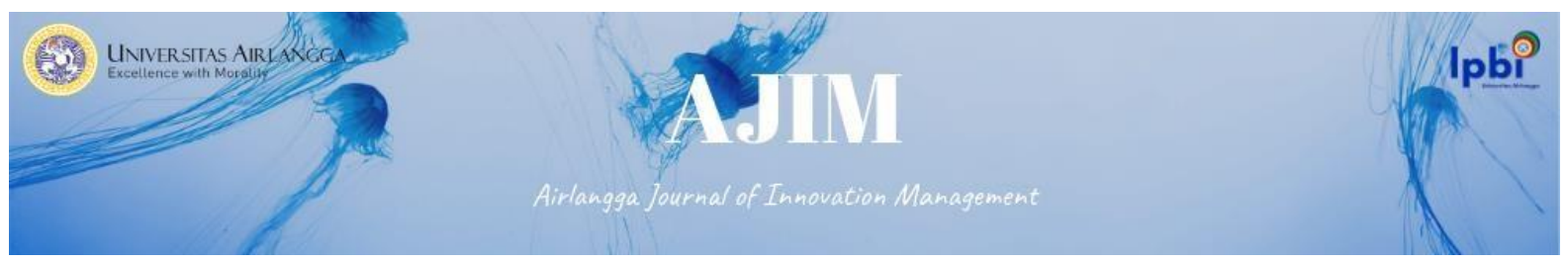

Vol. 2 No.2 Oktober 2021

e-ISSN: 2722-5062

DOI : 10.20473/ajim.v\%vi\%i.30232

\title{
UTILITY 1 SERVER ON QUEUE SERVICE (STUDY: BANK ACCOUNT NUMBER CONVERSION)
}

\author{
Johan Alfian Pradana* \\ Teknik Industri, Fakultas Teknik, Universitas Kadiri, Kediri, Indonesia \\ *Corresponding e-mail : zoehuntz34@gmail.com
}

\begin{abstract}
Fast-paced, precise demands and time minimization are dominant factors to support the service business. Service activities are always expected to be the best by customers, especially ABC bank customers. Since the information about account conversion, many customers have come to the bank. The server utility of the queue system plays an important role. One of them is about measuring the usefulness of queue system, average expectations of waiting times, and expectations of the number of customers in the system. Services that focus on providing services always experience long lines queue. Therefore, the queue theory is used to assess utilities, waiting for time expectations, and expectations of customer numbers. Research methods using system performance. The step of this research are first, calculate the value of speed, average service, service level, and performance of queue system. The result is a queue system of 1 server on average - working with a utility value of $83.5 \%$ and the highest in the 4th week, with an average expectation - average waiting time of 0.428 or 25.6 minutes and an expectation of the number of customers in the system of 4.8 or 5 customers. The role of 1 server has not been practical to minimize waiting time expectations. The implication that has not been realized is to compare the various bank brands by analyzing effective utility.
\end{abstract}

\section{Keywords: Queue System, Bank, Services, Customer}

\section{Introduction}

Fast-paced, precise demands and time minimization are dominant to support service business. Customer needs from aspect of quality and quantity as a step to improve service more effectively. An academic that provides service facilities as a fulfillment of customer needs. Quality of service is a parameter of how well to provide services with a level of satisfaction. Therefore, roles such as admin, teller, and server are significant to support the service reputation on Bank ABC. The topic of this research focuses on queues service.

Queues as a balance retain customers if the queue system is excellent (Mueen, 2020). Queue activity includes customers coming at a constant rate or variety to get the service (Jiang et al., 2015), especially account conversion. Customers who have obtained waiting for line numbers will wait to be served, automatically form a queue, and be in line until the service is complete Sari et al (2016), Botutihe et al (2018). Therefore, good service can be used as a service parameter. Queues cause waiting for activities 


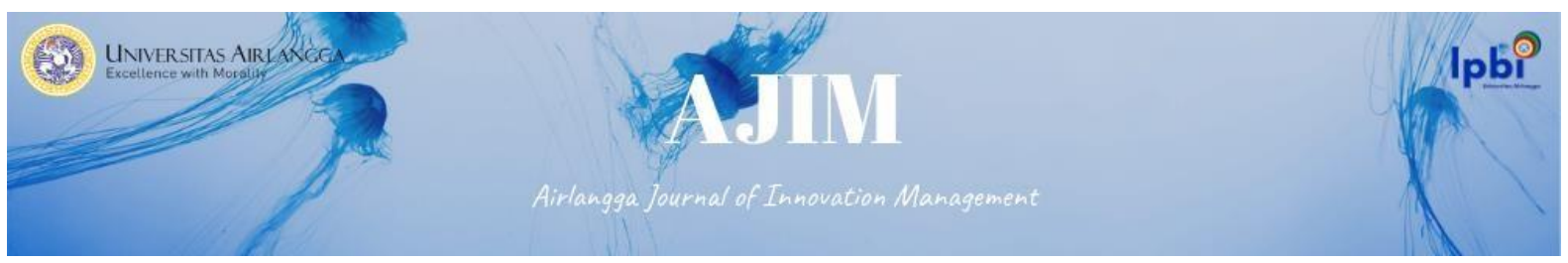

Aulele (2014). (Fedorenko et al., 2017) and waiting in queues is a common phenomenon in everyday life (Zhang et al., 2013).

Customer always expect that bank service has a better service activities, especially ABC bank customers. Since the information about account conversion, many customers have come to the Bank. However, the obstacle faced is a limited queue system. The queue system highlighted in this case only 1 server (Ďutková et al., 2019).

Existing procedures have been adhered to by customer. Customers who take the queue number must queue in order (Benelli \& Hassin, 2021). The queue discipline applied is that customer who comes first, will be served first. This caused the occurrence of long lines as an obstacle that can hardly be avoided. Therefore, dominant queuing activity wastes time. However, this serves as a step to get service. Duration of waiting time and acceleration of service as expectations to be achieved(Lyu et al., 2021).

The research reference is (Taufemback \& Da Silva, 2012), it states that a new, more practical approach to optimal commercial bank excess reserve management with queue theory is commonly used in other more established fields such as telecommunications and traffic engineering with waiting times of more than 15 minutes. Research of Satya Hermanto et al., 2018), stated that both time series approach and structural approach have pattern recognition which are good for waiting time estimates, but for queues of banking customers with complex causal factors, more research is needed in the future. Queue length, number of servers, and head of line factor should be noted for this purpose. In addition, the type of service should be considered to estimate service rate variables in queuing theory. Research of Hao \& Yifei, (2011) states situations 6 and 7 of the server, due to situation that may be changed by modification, $n$ parameters and $n$ functions $\operatorname{Max}(0$, Normal $(65,60))$ with fixed uptime. The average number of people in the queue is 5.29 when there are 6 servers. The waiting time is 339 seconds. When there are 7 servers, the average number of people in the queue is 1,782, and the waiting time is 121 seconds. At least someone was queuing when the number 7 was. But, given the whole situation, we suggest the number of optimized servers is 6 .

Based on the study's reference, the gap and novelty as a research opportunity are to assess utility comparison of 1 server in 5 weeks. This has never been done by research that has been studied. The purpose of this study was to show the role of average 1 server queue system - working average with utility value, average expectation - average wait time, and expectation of the number of customers in system. The scope of research covers 1 server, and analysis method is single-channel queue theory single phase - the benefits of this research as an evaluation of the ABC Bank on the applicable service system.

\section{Literature Review}

Service is a sequence of activities that directly interact between a person and another person or machine and provide customer satisfaction (Moshtagh et al., 2018)( Indrajaya and Cornellia, 2018). Elements in queue theory include input as customer-provided service and arrival pattern as a random variable (Yang et al., 2016 and Purnomo 2021). Furthermore, queue discipline is a priority of service delivery, length of queue as volume of queue capacity, system servants as parties who provide services, and output as parties that have been provided services(Cejka \& Šedivý, 2021) and (Susetyo and Nasution, 2019).

The queue discipline used is FIFO. FIFO as a customer who comes first will be served first (Mohammad Shyfur, 2013). Queue system categories selected single-channel direction - single phase as a path to enter the system, and there is only 1 service server. 


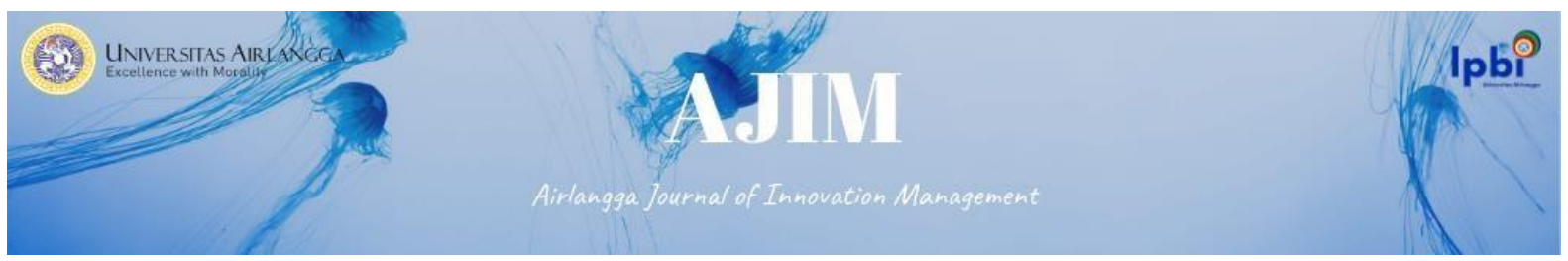

\section{Methods/Materials}

\section{Intrumen, Source of Data dan Research Variable}

Observation uses stopwatch instruments, stationery and Microsoft excel as the collection and processing of research data. The study's primary data source used observations at the ABC Bank Branch Office in Kediri. Observation for 5 Weeks, with weekdays Monday, Tuesday, Wednesday, Thursday, and Friday from 08.30 - 13.30 WIB. Primary data as a research variable covers the average number of arrivals and the average rate of customer service. The amount of customer data as respondents only covers account conversion services. Data averages the number of arrivals by recording the arrival time of each customer who enters the service system - average service time data by recording when the customer enters the service system until leaving the service server.

\section{Steps of Analysis}

The analysis stages for obtaining the utility value of the queue system are as follows:

1. Rate of arrival using formula equations (Hao \& Yifei, 2011):

$$
\lambda=\frac{\text { Total arrivals }}{\text { Observation time } \mathrm{x} \text { number of days }}
$$

2. Average service using formulas (Taufemback \& Da Silva, 2012):

$$
\text { average service }=\frac{\text { Total service time }}{\text { Population }}
$$

3. Service level using formulas (Bishop et al., 2018):

$$
\mu=\left(\frac{1}{\text { average service }}\right) \times 60 \text { minutes }
$$

4. Queue system performance with formulas (Bintari, 2015):

a) Average number of customers in the system $\left(\mathrm{L}_{\mathrm{s}}\right)$

$$
L_{s}=\frac{\lambda}{\mu-\lambda}
$$

b) Average number of customers in line $\left(\mathrm{L}_{\mathrm{q}}\right)$

$$
L_{q}=\frac{\lambda^{2}}{\mu(\mu-\lambda)}
$$

c) Average wait for customers in the system $\left(\mathrm{W}_{\mathrm{s}}\right)$

$$
W_{s}=\frac{1}{\mu-\lambda}
$$

d) Average waiting in line $\left(\mathrm{W}_{\mathrm{q}}\right)$

$$
W_{q}=\frac{\lambda}{\mu(\mu-\lambda)}
$$

e) The Intensity of service facilities $(P)$

$$
\mathrm{P}=\frac{\lambda}{\mu}
$$

f) Probability of no customers in the system $\left(\mathrm{P}_{0}\right)$

$$
P_{0}=1-\frac{\lambda}{\mu}
$$

g) Probability of customer in the system $\left(\mathrm{P}_{\mathrm{n}}\right)$

$$
P_{n}=\left(1-\frac{\lambda}{\mu}\right)\left(\frac{\lambda}{\mu}\right)
$$

h) Expectations of the number of customers in the system (L)

$$
\mathrm{L}=L_{q}+\frac{\lambda}{\mu}
$$

5. Comparison of queue system performance in Week 1, 2, 3, 4, and 5 . 


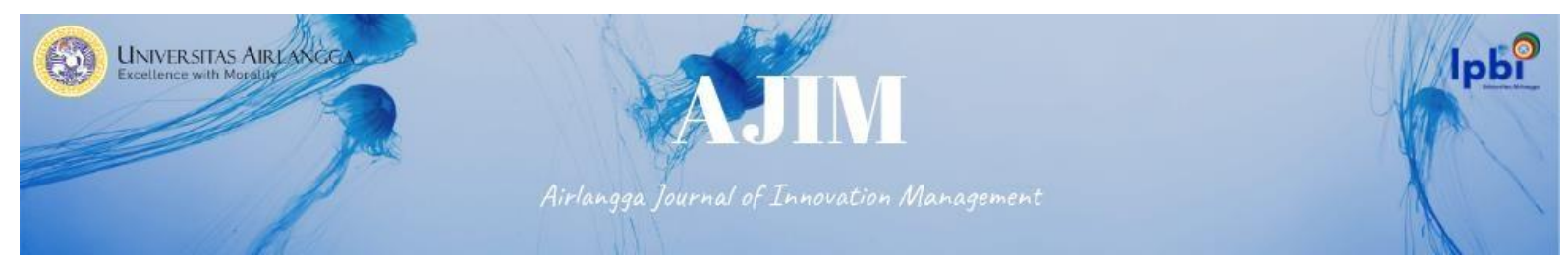

\section{Results and Discussion}

Recapitulation of observations with arrival rate $(\lambda)$, average service, service level $(\mu)$, queue system performance, and performance comparison for 5 weeks. The average aspect of customers number in system (Ls), Average number of customers in line (Lq), Average wait for customers in the system (Ws), Average is waiting in line (Wq), Intensity of service facilities (P), Probability of no customer in the system (P0) and Probability of customers in the system (Pn) (Jingjing \& Dong, 2012).

Table 1. Assessment of Aspects of Queue Theory

\begin{tabular}{|c|c|c|c|}
\hline Weeks - & $\boldsymbol{\lambda}$ & Average service & $\boldsymbol{\mu}$ \\
\hline 1 & 10,00 & 5,04 & 11,91 \\
\hline 2 & 9,00 & 5,56 & 10,79 \\
\hline 3 & 9,00 & 5,38 & 11,15 \\
\hline 4 & 9,00 & 5,67 & 10,59 \\
\hline 5 & 10,00 & 5,06 & 11,86 \\
\hline Average & 9,400 & 5,341 & 11,260 \\
\hline
\end{tabular}

(Source: data, 2021)

Based on table 1, service value $(\mu)$ highest in the first week of 11.91 . While the service value $(\mu)$ was lowest in the fourth week at 10.59. For 5 weeks observation of data obtained as a service analysis. Based on table 1, it states the average service - the longest dominant service week four for 5.67 minutes compared to week one at the earliest for 5.04 minutes.

Table 2. Assessment of Aspects of Queue Theory

\begin{tabular}{|c|c|c|c|c|}
\hline Weeks - & $\mathbf{L}_{\mathbf{s}}$ & $\mathbf{W}_{\mathbf{s}}$ & $\mathbf{P}$ & $\mathbf{P}_{\mathbf{n}}$ \\
\hline 1 & 6,00 & 0,524 & 0,84 & 0,135 \\
\hline 2 & 6,00 & 0,557 & 0,17 & 0,139 \\
\hline 3 & 5,00 & 0,465 & 0,16 & 0,156 \\
\hline 4 & 6,00 & 0,628 & 0,50 & 0,128 \\
\hline 5 & 6,00 & 0,538 & 0,84 & 0,132 \\
\hline Average & 5,800 & 0,543 & 0,500 & 0,138 \\
\hline
\end{tabular}

(Source: data, 2021)

Customers on the dominant system of 6 customers with the longest at time of 0.628 or 36 minutes. Therefore, the highest Intensity is 0.84 or $84 \%$, with the highest probability of no customer being 0.156 or $15.6 \%$.

Table 3. Queue System Analysis

\begin{tabular}{|c|c|c|}
\hline Weeks - & $\boldsymbol{\rho}$ & $\mathbf{P}_{\mathbf{0}}$ \\
\hline 1 & 0,840 & 0,160 \\
\hline 2 & 0,834 & 0,166 \\
\hline 3 & 0,807 & 0,193 \\
\hline 4 & 0,850 & 0,150 \\
\hline 5 & 0,843 & 0,157 \\
\hline Average & 0,835 & 0,165 \\
\hline
\end{tabular}




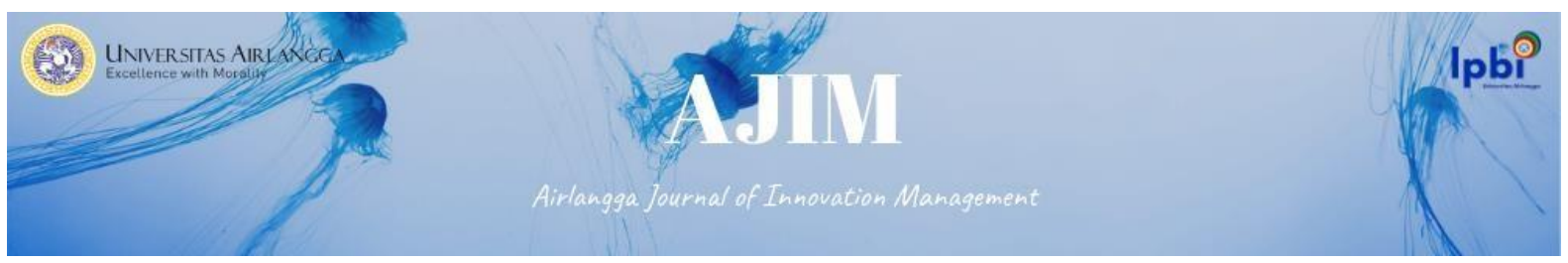

(Source: data, 2021)

Based on table 2, to find out the analysis of queue on converting savings accounts. This analysis does not do the addition of server facilities. Instead, it only reviews ratings for 1 server that is first in, first out.

The utility value of the system ( $\rho$ ), the highest at 0.850 , means that the busiest service is $85.0 \%$ in the 4th week. While the lowest of 0.834 means that a minor service occurs by $83.4 \%$ in the $2^{\text {nd }}$ week. The average utility value of the system utility $(\rho)$ is 0.835 or $83.5 \%$. The value of customers' absence in the system (P0) is most fantastic by 0.193 or $19.3 \%$ in the 3rd week. At the same time, the lowest is 0.150 or $15.0 \%$ in the 4 th week. The average value of customers' absence in the system (P0) is 0.165 or $16.5 \%$.

Table 4. Queue System Analysis

\begin{tabular}{|c|c|c|c|}
\hline Weeks - & $\mathbf{L}_{\mathbf{q}}$ & $\mathbf{W}_{\mathbf{q}}$ & $\mathbf{L}$ \\
\hline 1 & 4,00 & 0,414 & 4,72 \\
\hline 2 & 4,00 & 0,440 & 4,58 \\
\hline 3 & 4,00 & 0,367 & 4,04 \\
\hline 4 & 5,00 & 0,496 & 4,99 \\
\hline 5 & 4,00 & 0,425 & 4,81 \\
\hline Average & 4,200 & 0,428 & 4,8 \\
\hline
\end{tabular}

(Source: data, 2021)

The expected number of customers in the queue (Lq) is the largest at 5 customers, and the smallest is 4 customers. The maximum waiting time $(\mathrm{Wq})$ expectation is 0.496 hours or 29.4 minutes in week 4 , and the fastest is 0.367 hours or 22.02 minutes in week 3 . The expected value of the number of participants in the system (L) is highest at 4.99 or 5 customers in the 4 th week and at least 4.04 or 4 customers in the 3 rd week.

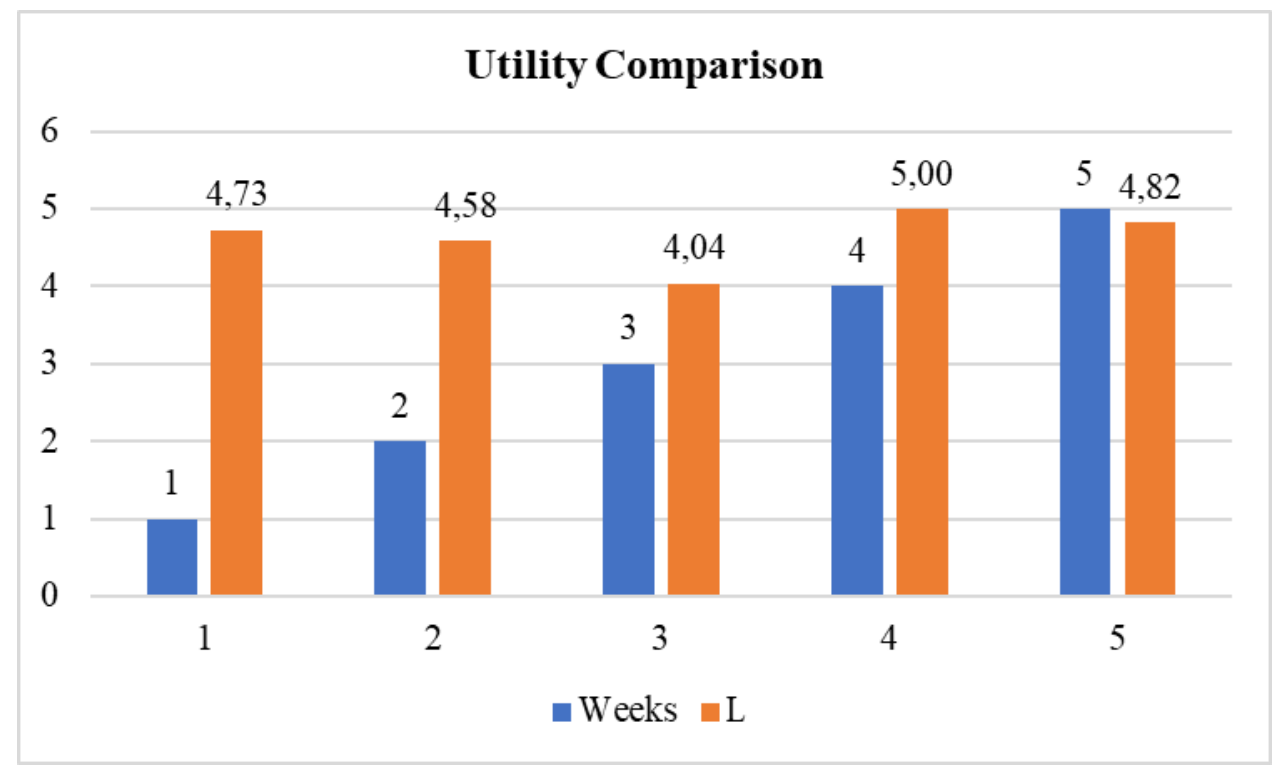

Figure 1. Utility Comparison 


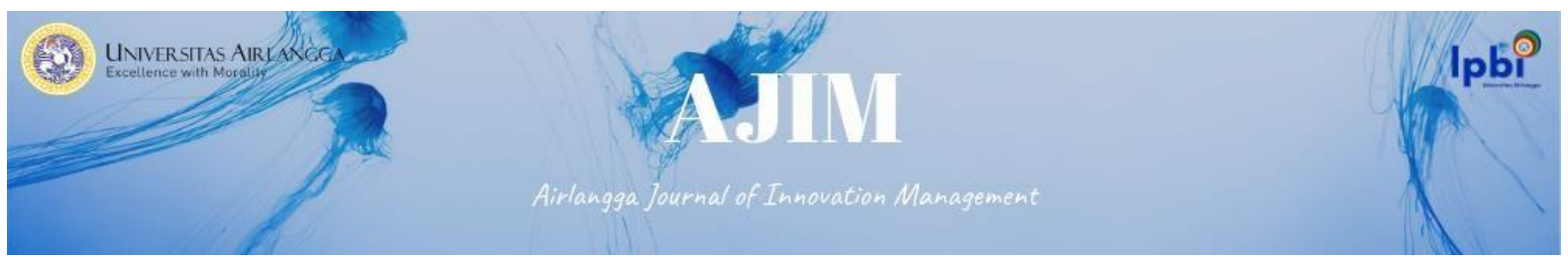

Based on figure 1 shows the highest utility in week 4 . That is, the 4th week states 1 server is in full use. While the lowest utility occurs in the 3rd week stated 1 server is used in full. Therefore, it is stated that the value of utility increases or decreases due to the level of customers provided by the service.

\section{Conclusion}

Based on the results of the study showed the role of the average 1 server queue system - working with an average utility value of $83.5 \%$ and the highest in the 4th week, with an average expectation the average waiting time of 0.428 or 25.6 minutes and the expectation of the number of customers in the system of 4.8 or 5 customers. The role of 1 server has not been effective in minimizing waiting time expectations. Therefore, future research can add simulations with more than 1 server. Previous research was dominant with observations of less than 5 weeks. Therefore, the update of the queue service system research increases the observation time to 5 weeks with a focus on converting account numbers and focusing on server utilities.

\section{References}

Aulele, S. N. 2014. "Analisis Sistem Antrian Pada Bank Mandiri Cabang Ambon," BAREKENG J. Ilmu Mat. dan Terap., vol. 8, no. 1, pp. 45-49, doi: 10.30598/barekengvol8iss1pp45-49.

Benelli, M., \& Hassin, R. (2021). Rational joining behavior in a queueing system with abandonments. Operations Research Letters, 49(3), 426-430. https://doi.org/10.1016/j.orl.2021.04.004

Bintari, H. (2015). Analisis Sistem Antrian Peserta Badan Penyelenggara Jaminan Sosial Kesehatan Surabaya. Sepuluh Nopember Institute of Technology.

Bishop, S. A., Okagbue, H. I., Oguntunde, P. E., Opanuga, A. A., \& Odetunmibi, O. A. (2018). Survey dataset on analysis of queues in some selected banks in Ogun State, Nigeria. Data in Brief, 19, 835-841. https://doi.org/10.1016/j.dib.2018.05.101

Botutihe,K., Sumarauw, J. S. B, Karuntu, F. 2018. Ekonomi dan Bisnis, and J. Manajemen Universitas Sam Ratulangi Manado, “Analisis Sistem Antrian Teller Guna Optimalisasi Pelayanan Pada Pt. Bank Negara Indonesia (Bni) 46 Cabang Unit Kampus Manado Analysis of Queue System and Optimization of Teller Service At Pt.Bank Negara Indonesia Branch of the Campus Manado," J. EMBA, vol. 6, no. 3, pp. 1388-1397.

Cejka, J., \& Šedivý, J. (2021). Discussion of operational transport analysis methods and the practical application of queuing theory to stationary traffic. Transportation Research Procedia, 53(2019), 196-203. https://doi.org/10.1016/j.trpro.2021.02.026

Duutková, S., Achimský, K., \& Hoštáková, D. (2019). Simulation of queuing system of post office. Transportation Research Procedia, 40, 1037-1044. https://doi.org/10.1016/j.trpro.2019.07.145

Fedorenko, V., Fedorenko, I., Sukmanov, A., Samoylenko, V., Shlaev, D., \& Atanov, I. (2017). Modeling of data acquisition systems using the queueing theory. AEU - International Journal of Electronics and Communications, 74, 83-87. https://doi.org/10.1016/j.aeue.2017.01.024

Hao, T., \& Yifei, T. (2011). Study on queuing system optimization of Bank based on BPR. Procedia Environmental Sciences, 10(PART A), 640-646. https://doi.org/10.1016/j.proenv.2011.09.103

Hermanto, R. P. S, Suharjito, Diana, and A. Nugroho. 2018. "Waiting-Time Estimation in Bank Customer Queues using RPROP Neural Networks," Procedia Comput. Sci., vol. 135, pp. 3542, doi: 10.1016/j.procs.2018.08.147.

Indrajaya, D. and Cornellia,R. 2018. "Analisis Model Antrian Loket Transaksi pada PT. POS Indonesia 


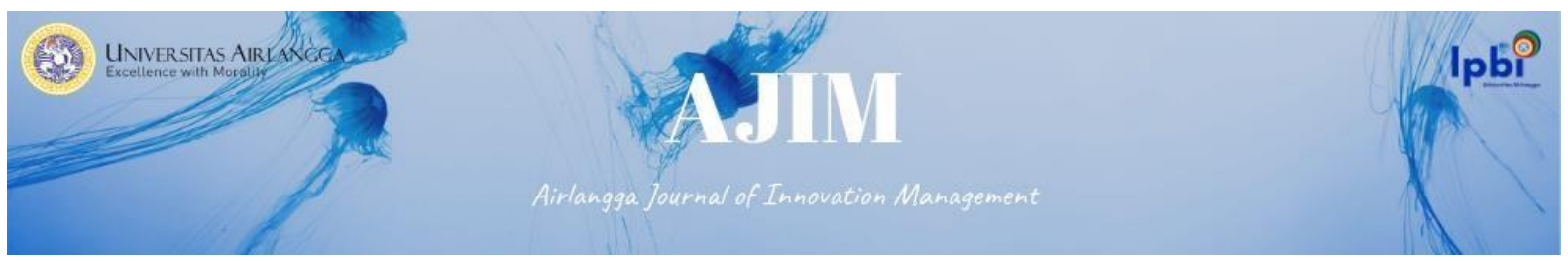

(persero) Kantor Cabang Sawangan dengan Menggunakan Software Promodel," STRING (Satuan Tulisan Ris. dan Inov. Teknol., vol. 3, no. 2, p. 170, doi: 10.30998/string.v3i2.2828.

Jiang, T., Liu, L., \& Li, J. (2015). Analysis of the M/G/1 queue in multi-phase random environment with disasters. Journal of Mathematical Analysis and Applications, 430(2), 857-873. https://doi.org/10.1016/j.jmaa.2015.05.028

Jingjing, X., \& Dong, L. (2012). Queuing Models to Improve Port Terminal Handling Service. Systems Engineering Procedia, 4, 345-351. https://doi.org/10.1016/j.sepro.2011.11.085

Lyu, X., Xiao, F., \& Fan, X. (2021). Application of Queuing Model in Library Service. Procedia CIRP, 188(2019), 69-77. https://doi.org/10.1016/j.procs.2021.05.054

Mohammad Shyfur, M. S. (2013). Solving Of Waiting Lines Models in the Bank Using Queuing Theory Model the Practice Case: Islami Bank Bangladesh Limited, Chawkbazar Branch, Chittagong. IOSR Journal of Business and Management, 10(1), 22-29. https://doi.org/10.9790/487x-1012229

Moshtagh, M., Fathali, J., \& Smith, J. M. G. (2018). The Stochastic Queue Core problem, evacuation networks, and state-dependent queues. European Journal of Operational Research, 269(2), 730748. https://doi.org/10.1016/j.ejor.2018.02.026

Mueen, Z. (2020). Estimating server utilization rate in single server queuing models using an approximate solution of stiff fluid flow model. Ain Shams Engineering Journal, 11(3), 805-809. https://doi.org/10.1016/j.asej.2019.12.006

Purnomo, B. H.., Suryadharma, and N. Y. Ekasari. 2021. "Model Sistem Antrian Pada Pelayanan Restoran Cepat Saji," J. Agroteknologi Vol., vol. 15, no. 01.

Satya Hermanto, R. P., Suharjito, Diana, \& Nugroho, A. (2018). Waiting-Time Estimation in Bank Customer Queues using RPROP Neural Networks. Procedia Computer Science, 135, 35-42. https://doi.org/10.1016/j.procs.2018.08.147

Sari, Sugito, and Warsito. 2016 "PENerapan Teori Antrian Pada Pelayanan Teller Bank X Kantor Cabang Pembantu Puri Sentra Niaga," J. Gaussian, vol. 6, pp. 81-90.

Shyfur, M.S.S. 2013. "Solving Of Waiting Lines Models in the Bank Using Queuing Theory Model the Practice Case: Islami Bank Bangladesh Limited, Chawkbazar Branch, Chittagong," IOSR J. Bus. Manag., vol. 10, no. 1, pp. 22-29, 2013, doi: 10.9790/487x-1012229.

Susetyo, J and Nasution, S. R. "Analisis Sistem Antrian Multiple Channel Untuk Kapasitas Terbatas," J. Ilm. Tek. Ind., vol. 53, no. 9, pp. 1689-1699.

Taufemback, C., \& Da Silva, S. (2012). Queuing theory applied to the optimal management of bank excess reserves. Physica A: Statistical Mechanics and Its Applications, 391(4), 1381-1387. https://doi.org/10.1016/j.physa.2011.09.022

Yang, K. K., Cayirli, T., \& Low, J. M. W. (2016). Predicting the performance of queues-A data analytic approach. Computers and Operations Research, 76, 33-42. https://doi.org/10.1016/j.cor.2016.06.005

Zhang, X., Zeng, Q., \& Chen, W. (2013). Optimization Model for Truck Appointment in Container Terminals. Procedia - Social and Behavioral Sciences, 96(Cictp), 1938-1947. https://doi.org/10.1016/j.sbspro.2013.08.219 